\title{
DIFFICULTIES IN IFRS TRANSLATIONS AND COMMUNICATING OF FINANCIAL INFORMATION: CASE OF NON-ENGLISH SPEAKING COUNTRIES.
}

\begin{abstract}
This paper examines the challenges that non-English speaking countries are facing while communicating their financial information prepared under International Financial Reporting Standards (IFRS). It also considers the difficulties in teaching the IFRS issues to non-English speakers. From the one hand, the research addresses the nature of the challenges which emerge through the linguistic translations of the IFRS. From another - it explores some of the procedures that are aimed to respond to these challenges.

We consider this paper to be of a particular interest for the non-English natives that use Financial Reports prepared under the IFRS, which include: the academics, practitioners and rulemakers. As it underpins the peculiarities of the teaching and communicating process in nonEnglish speaking countries.

The IFRS are proposed, discussed and issued by IASB and interested users in English, afterwards the standards go through the multi-language translations. We found an under investigated research area on how to produce the same quality regulation and teaching, as well as how to achieve the comparability in non-English speaking countries. Recent literature on the issue shows the importance of delivering a consistent and coherent message through the financial reports.

The purpose of this paper is to examine the experience from an accounting language perspective in Balto-Slavic and Koreanic language families. This particular choice is explained by non-belonging of these languages to a Germanic language family. The discussion is based on observation of the changes in accounting regulations along with the approaches to the accounting education. The results indicate that the IFRS adoption process in the countries with non-German native languages differs from country to country and that it cannot be based on the literary or verbatim translations, but needs to fit local peculiarities and what is more important - to consider local educational traditions.

Among the most important finding is that IFRS students do not have enough information on the IASB conceptual framework in average. This prevents them from the understanding their rights to express their view on the existing IASB initiatives. We have analysed the perceptions of a sample of non-English speaking students about their interest in IFRS and the challenges they face during the learning process.

Thus, we hope that the paper will add to the existing literature by the research of the educational issues, which outline the fact, that the lack of the appropriately trained accountants leads to certain difficulties that occur among the non-English speakers. We also come to the conclusion that new generation of students are digital natives and thus existing methods of training need appropriate changes.

The paper has further potential for spreading the discussion among the other non-English speaking countries. The limitations of the paper are viewed in the lack of local academic research on this theme provided in globally used and acknowledged databases. This leads to the difficulties in conducting the initial literature review.
\end{abstract}

Key words: IFRS, Translation, Accounting Standards Implementation, Communication of Financial Information, Digital Natives, Accounting Education

Introduction

International standardization attempts are keeping going on all over the world (Mennicken, 2008), but discussion of whether the translations of IFRS into different languages meet the goals of their nature is still opened. The rise and spread of the global rules affected accounting all over the world. In this regard non-English speaking countries have challenged 
different difficulties during the IFRS implementation process. While the main difficulties of the translation process refer to the field of pre translation analysis, description of different types of equivalents, typology of translation similarities, complex description of lexical, the meaning of the evaluation criteria on translation quality should not be underestimated.

This paper reviews the literature on this subject and incorporates the results of accounting framework changes occurred in non-English speaking countries. Thus, in the paper following a review of relevant literature the key issues that arise when implementing IFRS in non-English speaking countries are considered. Then, using these issues as a structure for the empirical analysis, the legislative and educational approaches to the IFRS translations within Russia, Turkey and South Korea are examined. This analysis is supported by the overview of instructional materials currently available in these countries. The further discussion contributes to the next three important issues. First, it aims to shed light on the translation issues that remain the center of the transnational accounting settings (Botzem \& Quack, 2006). Second, the circle and the role of peripheral actors that have been driving the translation and implementation processes are set. Third, by outlying the challenges of the cross-cultural harmonization, the connection of the world's business through translations becomes more obvious and achievable.

The paper is based mainly on the analysis of IFRS implementation process ongoing in the named non-English speaking countries that belong to the "expanding circle" of the diffusion model of English language (Kachru, 1990). By doing so paper contributes to the next important issues:

- the issues of the challenge's origin related to the linguistic (and non-linguistic) translation of IFRS in Balto-Slavic, Turkish and Koreanic language families that are still uncovered.

- the approaches to IFRS education adapted for creating the best background for global cooperation that remain unsettled.

Further, although there exists a strong need of the international comparability and credibility of the financial reporting, still the steps undertaken in this direction in those countries remain uninvestigated and underestimated. The situation is complicated by the lack of appropriate teaching and communicating tools that are suitable for the era of digital natives.

Global standards and models aim to increase international comparability (Braithwaite \& Drahos, 2000; Brunson \& Jacobsson, 2000). Although many attempts are made to translate and communicate accounting standards into local regulatory and professional framework in the described countries, it has been admitted that IFRS will not work by themselves and are not likely to contribute to the global harmonization without support (Gendron, Cooper \& Townley, 2007). In this regard, the examination of the network of actors of the process should represent a preliminary stage of the successful implementation. . The question of the broader investigation of the network of actors involved in defining principles of the operating in accordance with international standards was raised in previous research (e.g. Mennicken, 2008). However the problem of the "lessons not learned" (Plumlee et al., 2014) is still inherent. One of the main issues is seen in misunderstanding of the basic terms and principles by the global accounting network actors due to the cultural, linguistic and educational traditions.

Initially the global language system is represented by more than 7000 languages with more than 14 language families (Ethnologue, 2018). The paper examines the output of the countries that are united under the common language families in order to understand the meaning of the business language interactions. To provide this visibility we use data from the World Input-Output Database (Timmer et al., 2015).

We therefore hope that this paper can support the findings of the prior literature by illustrating that IFRS translation in non-English speaking countries still causes variety of misunderstanding and unequivalency.

\section{Literature review}


Past two decades influenced accounting theory and practice greatly in the sense of globalization,standardization and digitization. This resulted in that accounting language, especially in non-English speaking countries has undergone crucial changes. As it is suggested in recent accounting research devoted to the translation issues, accounting can be viewed as a field that has undergone massive changes recently (Fuertes-Olivera and Nielsen, 2014). The changes occurred during the past decades have led to the almost complete discarding of the existing beforehand in Financial Reporting framework. As a result there exists a certain need for modern lexicographical tools which are capable to capture the dynamics of accounting terminology nature (Fuertes-Olivera and Nielsen, 2011). Further, teaching and technological approaches also lack actualization in accordance to the existing level of development. In this regard, Baskerville and Evans research (2011) states that problems and limitation that occur during the IFRS translation process between languages also affect accounting practice and education .

From the educational perspective, in most non-English speaking countries accounting educators face problems in delivering unfamiliar concepts to students when teaching Accounting and IFRS courses. At the same time recent research acknowledges that although translation is possible, direct equivalence is mostly unachievable. In these circumstances the equivalent quality in global reporting can also be hardly achieved. There is certain evidence that both accounting educators and practitioners from non-English speaking countries were not prepared enough to the dramatic changes that occurred in their profession. In their research Bassnett and Trivedi (2012) outlined the common problem for those working in the field of translation studies: that is the relationship between the original text and the translation of that original. At the same time this issue is inherent in many other fields, e.g. law, medicine, etc. In this regard, the difficulties faced by translator arise because of the lack of suitable terminology and equivalent concepts (Brown, 1995). The essence of equivalent translation of accounting settings is caused by the importance of harmonization (Baskerville and Evans, 2011) and global economy demand. In its turn, using special accounting terms can lead to the misunderstandings when the meaning of such terms is not fully appreciated by the recipient of the information (Evans, 2004).

Moreover the adequate and equivalent translation requires certain changes in national framework for the regulation of accounting processes. This can be achieved by consecutive iterations starting from accounting education re-modeling. While teaching accounting in the international cohort is always a challenge, not only the communication difficulty is an issue. There is a more complicated problem which lays in the lack of the equivalent terms in the languages from the non-Germanic family. Thus promoting the equivalent interpretation and better understanding of accounting terminology (Baskerville and Evans, 2011) can help to adopt IFRS in non-English speaking countries.

In the age of information technologies and globalized world the translation by itself is not a big issue anymore, as it can easily be done automatically and without any need of human interfering. Thus the importance of this process, by itself, in the modern world reduces that argues Catfords' (1965) suggestion about its linguistics issue. In contrary, understanding and interpretation of the translated material is a subject of interest not only for linguists, but for professional accountants and students. On the background when English language is supposed to create a common standard for communication that is likely to promote better understanding and transparency among people the implications of translation problems for smaller language communities, especially those which are not part of Germanic languages family have strong potential to be exploited in ideologically or pragmatically motivated distortions in the implementation of accounting regulation (Evans, at al., 2015).

For instance, it appears that native language has effects on how speakers of different languages interpret uncertainty expression in a certain language (e.g. native English speakers and German speaker do not interpret English uncertainty expression in the same way) (Doupnik \& Richter 2003). This has more strong impact on the non-Germanic family languages and as a result inconsistencies in the interpretation of these expressions in the financial statements reduce the comparability of the financial statements. (Kettunen, 2011). 
Moreover, the results of addressing to the recent financial reporting issues research in Central and Eastern European countries indicate its massive orientation on fiscal and government users which is rooted deeply in communist regime (McGee and Preobrazhenskaya, 2005; Prochazka, 2011; Vysotskaya and Prokofieva, 2013).

Therefore the difficulties of IFRS translation should be viewed from the two mutually sharp points: translating and interpreting; and from the notion that the translated resources that are used both in accounting education and accounting practice processes cannot be verified by the original language representatives. This brings modern accounting standardization to a gap that traditionally can hardly be bridged.

Meanwhile, the individuals should have a possibility to make the communication of their financial information more effective. Thus financial information is supposed to be delivered in a way that allows its users to make assessments and financial decisions based on successful navigation through the financial statements.

Recent research indicates some of the most difficult for translation special terms in order to understand factors of the greatest influence. Each translation is a subject of a certain limitation of such common situation as: "the words may be understood, but the concept may not be understood" (Zeff, 2007). This in a broad sense means that the translation should not be verbatim or literal. As a separate phenomenon, translation, should aim to transmit all the shades of meaning, not limited to separate words or verbal constructions.

\section{Accounting framework development and IFRS implementation in Balto-Slavic language group}

Analysis of Balto-Slavic countries' experience of implementing the IFRS is based on the cross-country study of the 10 representatives of this language family: Bulgaria, Czech Republic, Estonia, Croatia, Lithuania, Latvia, Poland, Russia, Slovak Republic, and Slovenia. The main steps that were analyzed in the paper refer to the changes that occurred after the transition from planned economy towards market that took place in most of the named countries. Basically, changes in economy style reflected in changes of accounting regulations that are represented mostly by issuing of upgraded versions of accounting laws (Table 1).

\section{Insert Table 1 about here}

The table 1 initially shows how the process of IFRS adoption undergone in Balto-Slavic language-speaking countries that belong to the third, 'expanding' circle of English language (Kachru, 1990). There is a certain part of evidence that English language spreading coincided with the fall of planned economy, promoted by the Soviet Union. From the business language perspective it is also difficult to estimate the total countries and languages, belonging to this expanding circle. We hope that our paper will add to the existing literature by findings that almost in all Balto-Slavic countries first IFRS translations, which were officially approved, appeared almost a decade later than the transformational processes began. Thus time-period lag of about 10 years appeared between the language used by the economic entities worldwide and variations (and interpretations) of which were used in Balto-Slavic countries.

In their paper McGee and Preobrazhenskaya (2005) stated that accountants who can read the international standards in the original English have a competitive advantage, as they have an opportunityto consult the English original version of IFRS at least (Baskerville and Evans, 2011). However, in some countries of the described regions (e.g., Russia) there can hardly be 
found at least one accounting educational program that is delivered in English. At the same time the importance of providing professional accountants with thorough understanding of special terms is obvious. This issue becomes even more important when assessing the employability skills expected from accounting graduates (Stoner and Milner, 2010).

Given that there can hardly be found an economic course being delivered in English language in Russia, IFRS courses are used to be delivered only in Russian as well. Moreover, IFRS courses at the university level usually include a very broad discussion of the accounting components and do not specify IFRS disciplines in accounting specialization (Vysotskaya and Prokofieva, 2013).

Represented data show the dynamics of IFRS adoption process in Balto-Slavic countries (Figure 1). As it appears, the shortest period for this was required for Lithuania (8 years) and the longest - for Russia (18 years). Though, accounting regulation changes in Lithuania started at 1997, that is 3 years later than in the most of analyzed countries.

\section{Insert Figure 1 about here}

The reason of such a slow adaptation process in Russia may lay in the fact that only $15 \%$ of the popularity knows a foreign language ${ }^{1}$, from which $80 \%$ refers to English language. In contrast to other countries of this language family group, where the knowledge of English language is averagely at the point of $33 \%{ }^{2}$.

\section{Accounting Regulation in Russia}

The analysis of the Russian case adds to the understanding of Accounting Regulation development in post-Soviet Union countries. Since historically Russian accounting was thoroughly influenced by the government, the paths of its future development are mostly determined by the authority bodies. Official professional regulation of accounting started from 1802 when the Ministry of Finance was established. Since then, the state and public institutes' management aimed to provide necessary revenues to the government for its maintenance. Besides, Minister of Finance was obliged to prepare the detailed report of the general government expenditures at the end of each year. During the 1810-1811 the Ministry of Finance has undergone a transformation. Since then the duties of the Ministry spread into three directions: 1) the responsibility for controlling the sources of the income, 2) the responsibility for the cash flows, 3) the responsibility for the audit of all accounts.

By 1817 Ministry of Finance functions were accomplished by manufactories and internal trade control. In 1820s Ministry of Finance has issued several decrees which caused growth of the governmental influence on the factory owners and workers. By 191721 Ministers of Finance have changed. Each of them had a remarkable background, as different as the measures they have undertaken during their official status" ${ }^{3}$. In 1918 several Decrees on the "Government Control" were issued. This has led to creating the "Central State Accounting" body which marked the beginning of the statistics' development in Russia. The reporting forms and chart of national accounts were established in 1922 by the "Regulations on Accounting and Reporting"

\footnotetext{
${ }^{1}$ Knowledge of foreign languages in Russia (in Russian). Levada Centre. 16 September 2008, available at: http://www.levada.ru/16-09-2008/znanie-inostrannykh-yazykov-v-rossii (accessed 10 June, 2015)

${ }^{2}$ Europeans and their Languages, available at: http://ec.europa.eu/commfrontoffice/publicopinion/archives/ebs/ebs 386 en.pdf (accessed 10 June, 2015)

${ }^{3}$ Ministry of Finance official website, available at: https://www.minfin.ru/ru (accessed 15 June 2017)
} 
along with the main framework for public companies - stated by "Regulations on Public Reporting".

The most dramatic changes in Russian accounting occurred after the collapse of Soviet Union. This period was started with a market-oriented legitimation of commercial activities, from 1994, when "Law on Accounting" was issued.

Russian accounting is being changed for more than 18 years already. Since 2012 IFRS became mandatory, in accordance with the Federal Law 208-FZ 'On Consolidated Financial Statements'. Nevertheless, there still remain several cases when some kinds companies must prepare their financial statements under Russian Accounting Standards.

To summarize, it should be noticed that transition process towards IFRS implementation in Russian Federation began in 1994, when the "Program of Reforming the Accounting System" was declared. It stated that the process should be completed by 2000. This Program was followed by several "Concepts of Accounting" issued in 1997, 1998, and 2004 which also prescribed certain steps to be undertaken in order to complete IFRS adoption.

The existence of the IFRS translation's problems becomes even more obvious when looking through the translation process in the countries that have been using Russian language as a state one for decades, e.g. Ukraine, Belarus, Uzbekistan, etc. Since their accounting systems have roots in Soviet Union and primarily used Russian language, their accounting systems seem to face identical problems.

In regard of the English-Russian translation L. Mirzoyeva (2014) states that the process of economic terms translation should take into account such characteristics of many economic terms as their metaphorical color, as the adequate representation of the metaphorical will help to deal with the existing variety of transformations.

Russian IFRS translation issues mainly refer to such terms as: assets, comprehensive income (basically is mixed with income and profit), provisions, allowance, etc. In contrast, among the most difficult terms for the translation in Korean language are mentioned those that refer to likelihood, as: virtually certain, substantially all, highly probable, reasonably certain, possible, (un)likely, etc.

Since the educational aspect has a great impact on IFRS adoption process, we provide a summary of the key text-books on IFRS adoption available in Russian in order to outline the routs and tendencies in teaching IFRS in Russia. Appendix 1 contains an analysis of the textbooks indexed by Russian Citation Index ${ }^{4}$ (RCI) system and some insights into authors' backgrounds.

Among 99 results of the search for the books which contain "IFRS" in their title, key words or annotation, only 18 refer to educational materials on IFRS, involving 31 authors. The further analysis is provided by the date of publishing and author's activity of publishing in English language.

We also should state that the fact that there is no single text book in English language makes Russian IFRS education resources unavailable for international auditory and, thus, for the international students.

\section{Insert Figure 2 about here}

From the perspective of the RCI database an increased raise of the IFRS-related textbooks publishing can be viewed. This is partly because of RCI database was started as a project at 2005 and not all related to that period publications were included in the named citations index.

\footnotetext{
${ }^{4}$ Scientific Electronic Library, Available at: https://elibrary.ru/defaultx.asp (accessed 01 June 2017).
} 
Although IFRS are originally created in English language and there exists the immense quantity of supportive literature for facilitating the transformation process, Russian educational literature does not provide sufficient literature review. This might be a reason of the enormous volume of difficulties that accountants face with after their graduation during their professional work. Thus there is certain evidence that Russian Accounting Education is not likely to be able to meet the global requirements without changing the approach.

In their research McGee and Preobragenskaya in 2005 stated that practitioners, affiliated with international accounting and audit companies consider that materials they provided for instruction and the resources they had to draw upon were of superior quality to those available in universities. Still this problem was not raised in time and didn't draw enough attention from the accounting academics and practitioners.

\section{Insert Figure 4 about here}

There is also a geographic skew towards the central part of the country, as it goes from the Figure 4. Thus, only 5 text-books were written by the authors that were not affiliated with central cities of Russia (Moscow and St. Petersburg). This states the problem of the educational quality in peripheral parts of the country.

Moreover, there is a serious issue with the visibility of Russian accounting educators on the global arena of research. By their nature, faculty positions at the universities all over the Russian Federation are associated with a certain part of research. However, from the Figure 5 it is obvious that only $1 \%$ from the selected part of the authors have publications in the journals that are included in the worldwide citation index.

\section{Insert Figure 5 about here}

We hope these results add to the existing literature by providing a clear picture of the quality of the IFRS education within Russian Federation. These results can be used to outline the future steps of its improvement. From this regard, we suggest to conduct more translation work on teaching materials. Since no Russian resources were approved as qualitative translation of teaching materials on IFRS that can be recommended for educational purposes at the Universities, it is essential to provide students with materials that can help to understand the metaphorical color of the basic principles and standards, along with the variety of their transformations.

\section{Accounting development and IFRS transition in South Korea}

Similarly to Russia, South Korea historically refers to the countries with strictly regulated and collectivistic features (Henderson, 2015). Moreover, Korean accounting system was affected by cultural characteristics. This resulted in creating a rules-based accounting system. This may partly explain the difficulties that country faced while undergoing the IFRS adoption process. 
Nevertheless, Korean accounting system continuously changed from rules-based towards principle-based accounting.

The largest part of research regarding IFRS adoption in Korea is hidden under the curtain of Hangeul, but some internationally published papers were useful in understanding the main trends in the related literature and provide the readers with some implications for the future empirical research in this area.

After the Asian crisis of 1997, South Korea established a private-sector accounting standard setting organization in 1998. As South Korea undertaken the path to implement IFRS fully and English language is not commonly spread all over the country, a certain need for IFRS translation existed. The first translation was issued in 2007 and showed that there are certain difficulties in translating certain English expressions into Korean language (KASB, 2016).

IFRS development in South Korea was followed by the requirement that all listed Korean companies should use IFRS beginning from 2011. This inevitably caused certain changes in accounting standards' paradigm and lead to the availability of all financial instruments (Soo and Soo, 2008). Thus, Korea adopted IFRS within 13 years, though Korean language has no single sign or meaning that can be compared with English. In this regard, it appears that the language cannot be considered as the main issue that prevents or complicates the IFRS adoption.

South Korea has a distinctive understanding of the IFRS adoption need which concludes, from the one hand, in realizing that IFRS implementation will make their accounting standards, along with the local market, more comfortable for investments and from the other, will allow local companies to differentiate themselves without boarders (Henderson, 2015).

Studies by Kwon, et al. (2017) provide evidence of improvement in earnings quality due to Korea's mandatory IFRS adoption. Such conclusion seems to be reasonable, since according to the empirical analysis made by Balsmeier and Vanhaverbeke (2016) it provides an evidence of South Korea's success in IFRS implementation in contrast to the Russian case. The sample break down by country outlines the details on country-specific rules regarding the adoption of IFRS by private firms (Table 2).

Insert Table 2 about here

Further, we found that apparently, South Korea is much more concerned about the quality of accounting education. This is proved by the evidence of teaching materials which are used in Korean Universities, and which are related to Accounting (e.g. 2017 Book Catalog, suggested by Jiphil Media, refers to 18 Accounting text-books ${ }^{5}$ ) and presented by mostly Korean authors. Among those 16 textbooks are available in English language. Among them, 6 are related to IFRS directly and provide students with the possibility of continuous using common English terms in professional area. Though historically University's curricula mostly reflected the policies and procedures dictated by K-IFRS, starting from 2009, all universities are required to teach IFRS. However not all the courses are delivered in English.

\section{The peripheral actors driving the translation and implementation processes}

In this part pf the paper, we summarize our findings from the research on IFRS adoption and translation facilitation that are needed in order to understand the focus, circle and role of peripheral actors. The international standardization process is a day-to-day process of the activities driven by local, peripheral actors, who try to support and shape standardizing agendas

\footnotetext{
${ }^{5}$ Jiphil Media Book Catalogue, available at: http://jiphil.co.kr/shop/m_mall_list.php?ps_ctid=06000000\&PHPSESSID=aeb3bb5385d21054642261023f78b834 (accessed 20 June 2017)
} 
in local settings in the framework of making changes for globally integrated and understandable world (Burawoy et al., 2000; Menninken, 2008).

From the broad view, accounting standardization has a specific set of actors which differ by their attitude to the adoption process. Thus, there we outline 3 main groups of actors: central, medial and peripheral.

\section{Insert Figure 6 about here}

Figure 6 represents the existence of three interconnected worlds: Accountants, Government and Translators along with Educators and Students.

In order to understand the perceptions of the students on the IFRS teaching process, we designed the questionnaire (Appendix 1) and held the survey among the non-English speaking students asking about their attitude towards the IFRS education process and their language possible difficulties while learning the IFRS.

We also eliminate three main types of the interaction between the circles on the Fig.6. We find therefore that the Accountants are strongly connected with the Government. This kind of connection is stronger in the countries where economy is more regulated by the government, e.g. Russia and South Korea. In their turn, Government bodies are interlinked with translators and educators. This kind of connection depends also on the role that is played by the government in this process. At least, Translators and Educators should be in strong connection with Accountants that belong to the inner circle. Here we come to an assumption that such kind of connection can affect the quality of the IFRS implementation process.

\section{Discussion and conclusions}

Since the paper is devoted to the analysis of the accounting system development in nonEnglish speaking countries (Russia and South Korea), it looks at the history, translations and teaching issues of IFRS in order to provide a broader international perspective of this arena and to contribute to the issues of finding common mistakes and, in contrast, the best practice in IFRS implementation process. This is done by describing the overall context of accounting education in those countries and their experience in implementing of IFRS within the existing accounting systems and the systems of higher education.

The history of accounting development in Russia and South Korea has much in common, since government played the most significant role in accounting regulation for many years in these countries. As the common case for Russia and South Korea is that English language is not widely spread among business entities, some of the terms used in IFRS cause certain difficulties in translating when preparing the financial reporting.

The IFRS adoption process in Balto-Slavic languages differs from country to country. However there are no sufficient differences in the Western side, where English language is more commonly used.

Implementation of IFRS within countries that do not belong to Germanic language family cannot be based on the literary or verbatim translations, but needs to fit local peculiarities. It took averagely 13 years for these countries to adopt IFRS. Still the quality of IFRS translations differs from country to country.

The circle of peripheral actors of IFRS adoption process should be provided with a comprehensive analysis of the existing educational resources for IFRS teaching and accounting standards setting.

Educational system and existing education programs on IFRS teaching of the various Russian Universities are not yet prepared to offer adequate resources for studying IFRS. Current 
Russian IFRS research does not refer to the original language and differs in several important ways. Since, conducting such research requires certain skills that need time to obtain, these conflicts seem to be hardly resolved in the near future. About a decade ago there was mentioned that the materials the international firms use are often in English, while materials used in the Universities in Russia are mostly in Russian. But this fact resulted not only in the issue that the Universities had a translation problem from English to Russian, but also in the problem that they cannot provide appropriate understanding of the international accounting standards along with the situation when that or another standard should be used. Therefore the predictions made by McGee and Preobragenskaya in 2005, namely, about the issue that not all the academics are able to read the international standards in the original English and will have to rely on the Russian translation are likely to come true, ass the mistakes that the translated materials contain are continuously repeated by the authors of educational materials.

We can also observe the situation with the lack of properly educated accountants which lead to different difficulties, both in education and professional area. The example of Korean attitude to Accounting Education shows that successful IFRS adoption should be started from the relevant accounting education accompanied with the adequate teaching materials that will be useful not only inside the University, but in professional area as well.

\section{References}

Alver, Lehte, Alver, Jaan and Liis Talpas (2014). Implementation of IFRSs and IFRS for SMEs: the case of Estonia. Accounting and Management Information Systems, 13 (2), 236-258.

Balsmeier B. and S. Vanhaverbeke (2016). International Financial Reporting Standards and Private Firms' Access to Bank Loans. European Accounting Review, p.1-30.

Bassnett, S. and Trivedi, H. (2012). Postcolonial Translation: Theory and Practice. Routledge.

Baskerville, R.F. and Evans, L. (2011). The darkening glass: Issues for translation of IFRS, Institute of Chartered Accountants of Scotland, Edinburgh.

Botzem, Sebastian and Sigrid Quack (2006). Contested rules and shifting boundaries: International standard setting in accounting. In: Djelic, Marie-Laure and Kerstin SahlinAndersson (eds.): Transnational Governance. Institutional Dynamics of Regulation. Cambridge: Cambridge University Press, 266-286.

Brown, C. E. (1995), 'Riding the Waves of Fortune: Translating Legislation of the Successor Soviet Republics' in Marshall Morris (ed.) Translation and the Law, American Translators Association Scholarly Monograph Series Volume VIII, John Benjamins Publishing Company, Amsterdam, Philadelphia, pp. 67 - 83.

Brunsson, Nils and Bengt Jacobsson (2000). A World of Standards. Oxford: Oxford University Press.

Burawoy, M., Blum, J. A., Sheba, G., Gille, Z., Gowan, T., Haney, L., Klawiter, M., Lopez, S. H., O'Riain, S., and M. Thayer (2000). Global Ethnography: Forces, Connections, and Imaginations in a Postmodern World. Berkeley: University of California Press.

Catford, J. C. (1965), A Linguistic Theory of Translation: An Essay in Applied Linguistics, Oxford University Press, London

Ethnologue, (2018), 21st edition website available at: https://www.ethnologue.com/ethnoblog/gary-simons/welcome-21st-edition (accessed 5 October, 2018)

Evans, L. (2004), "Language, translation and the problem of international accounting communication", Accounting, Auditing \& Accountability Journal, Vol. 17, No. 2, pp. 210-48.

Evans, L., Baskerville, R., \& Nara, K. (2015), "Colliding Worlds: Issues Relating to Language Translation in Accounting and Some Lessons from Other Disciplines", Abacus, Vol. 51, No.1, pp. 1-36.

Fuertes-Olivera, Pedro A. and Sandro Nielsen (2014). The dynamics of accounting terms in a globalized environment: The role of English as Lingua Franca, in Temmerman, R. and 
Campenhoudt, M. V. (eds) Dynamics and Terminology: An Interdisciplinary Perspective on Monolingual and Multilingual Culture-Bound Communication. John Benjamins.

Fuertes-Olivera, Pedro A. and Sandro Nielsen (2011). The Dynamics of Terms in Accounting: What the construction of the accounting dictionaries reveals about. Terminology 17:1 (2011), 157-180.

Gendron, Y., Cooper, D. J., and Townley, B. (2007). The Construction of Auditing Expertise in Measuring Government Performance. Accounting, Organizations and Society, 32(1/2), 101-129.

Hayes, D. (2011). Future focus: South Korea report. The Accountant. June 2011, available at: http://www.theaccountant-online.com/news/future-focus-south-korea-report (accessed 15 May 2017)

Henderson, Rebecca (2015). South Korea's Transition from K-GAAP to IFRS. University Honors Program Theses. 143, Georgia Southern University.

Inter-Country Input-Output (ICIO) reports: World Input-Output Database (2014), available at: http://www.wiod.org/database/wiots16 (accessed 06 March 2017)

Kachru, B. Braj (1990). The Alchemy of English: The Spread, Functions and Models of Non-native Englishes. Urbana and Chicago: University of Illinois Press.

KASB, Korean Accounting Standard Board, (2016). Accounting Judgments on Terms of Likelihood in IFRS: Korea and Australia. KASB Research Report No.39/AASB Research Report No. 2: www.kasb.or.kr (25.05.2017)

Kettunen, J. (2011, April). Translation of IFRS standards into local languages: Understanding procedures and problems of translation. Working paper presented at the EAA Annual Conference, Rome.

Krzywda, D. and M. Schroeder (2007). An Analysis of the Differences between IFRS and Polish Accounting Regulation: Evidence from the Financial Statements of Listed Entities on the Warsaw Stock Exchange for the Calendar Years Ending 2001, 2003 and 2004. Accounting in Europe, vol.4 (1), pp 1-29.

Kyong, Ung Soo and Han, Myung Soo (2008), A study on the introduction of IFRS \& the tangible asset valuation Appraisal studies Vol.7 No.1 (series No.9) p. 47-72.

Kwon S.Y., Na K and J. Park (2017). The economic effects of IFRS adoption in Korea. Asia-Pacific Journal of Accounting \& Economics, p. 1-41.Mackevicius, J., Strouhal, J. and Zverovich, S. (2008) Comparative analysis of the national accounting standards of the Czech Republic and Lithuania. European Financial and Accounting Journal, 3 (4). pp. 22-44. ISSN 1802-2197, available at: http://eprints.uwe.ac.uk/12747 (accessed 10 June 2017).

McGee, Robert and Galina Preobragenskaya (2005). Accounting and Financial System Reform in a Transition Economy: A Case Study of Russia. New York: Springer, 2005. 182 pages.

Mennicken, Andrea (2008). Connecting worlds: the translation of international auditing standards into post-Soviet audit practice. Accounting, Organizations and Society, 33 (4-5). pp. 384-414. ISSN 0361-3682.Mirzoyeva, Leyla (2014). Metaphorical Economic Terms: Problems Of Their Translation

From English Into Russian. Procedia - Social and Behavioral Sciences 136 ( 2014 ) 169 - 174.

Novak, Aleš and Aljosa Valentincic (2017). The Role and Current Status of IFRS in the Completion of National Accounting Rules - Evidence from Slovenia, available at: $\underline{\text { https://ssrn.com/abstract=2929058 }}$ or http://dx.doi.org/10.2139/ssrn.2929058 (accessed 15 May 2017).

Plumlee, R. and P. Reckers (2014). Lessons Not Learned: Why is There Still a CrisisLevel Shortage of Accounting Ph.D.s?. Accounting Horizons 28:2, 313-330.

Report on the observance of standards and codes (ROSC) Bulgaria. (2008) Accounting and auditing, December, available at: https://openknowledge.worldbank.org/bitstream/handle/10986/20433/625470REVISED00lgaria 0200800PUBLIC0.pdf; sequence=1 (accessed 09 March 2017). 
Sarikas, R. H., and A.M. Djatej (2005). History and the Russian accounting transition. International Journal of Accounting, Auditing and Performance Evaluation 2 (1/2): 54-66.

Sodan, Slavko and Barac, Zeljana (2017). The Role and Current Status of IFRS in the Completion of National Accounting Rules - Evidence from Croatia (February 27, 2017). Forthcoming in Accounting in Europe, a journal of the European Accounting Association, available at: https://ssrn.com/abstract=2928710 (accessed 15 June 2017).

Sucher, Patricia and Irena Jindrichovska (2004). Implementing IFRS: A Case Study of the Czech Republic, Accounting in Europe, 1. 2004, 109-141.

Stoner, G. and Milner, M. (2010). Embedding generic employability skills in an accounting degree: development and impediments. Accounting Education, 19 (1-2). pp. 123-138.

Timmer, M.P., E. Dietzenbacher, B. Los, R. Stehrer and G.J. de Vries (2015). An Illustrated User Guide to the World Input-Output Database: the Case of Global Automotive Production. Review of International Economics, 23(3): 575-605.

Vysotskaya, Anna and Maria Prokofieva (2013). The Difficulties of Teaching IFRS in Russia. Issues in Accounting Education: May 2013, Vol. 28, No. 2, pp. 309-319.

Žárová, M., Mejzlík, L. (2009): Have IFRS Positive Impact on the Regulatory Accounting Systems in Continental European Countries? European Financial and Accounting Journal, 2009, vol. 1, no. 1, pp. 5-24.

Zeff, S. (2007), 'Some Obstacles to Global Financial Reporting Comparability and Convergence at a High Level of Quality', The British Accounting Review, 39 (4), pp. 290-302. 
Table 1. Accounting and IFRS development in Balto-Slavic countries

\begin{tabular}{|c|c|c|c|c|}
\hline Country & Year & Accounting changes & IFRS & Source \\
\hline \multirow[t]{5}{*}{$\begin{array}{l}\text { Bulgaria } \\
\text { (13 years) }\end{array}$} & 1991 & $\begin{array}{l}\text { Accountancy Act and } \\
\text { National Chart of } \\
\text { Accounts issued }\end{array}$ & & \multirow[t]{5}{*}{$\begin{array}{l}\text { Report on the observance } \\
\text { of standards and codes } \\
\text { (ROSC) Bulgaria. (2008) }\end{array}$} \\
\hline & 1993 & $\begin{array}{ll}\text { National } & \text { Standards } \\
\text { application } & \end{array}$ & & \\
\hline & \multirow[t]{2}{*}{2001} & \multicolumn{2}{|c|}{ Joined the EU } & \\
\hline & & New Accountancy Act & & \\
\hline & 2003 & & $\begin{array}{l}\text { Adoption, } \\
\text { IFRS translation }\end{array}$ & \\
\hline \multirow{6}{*}{$\begin{array}{l}\text { Czech } \\
\text { Republic } \\
\text { (15 years) }\end{array}$} & 1991-1993 & $\begin{array}{l}\text { Adoption of Accounting } \\
\text { Act }\end{array}$ & & \multirow{6}{*}{$\begin{array}{ll}\text { Mackevicius, et al., } & \text { al } \\
\text { 2008; Sucher } & \text { and } \\
\text { Jindrichovska, 2004 }\end{array}$} \\
\hline & 2000 & & IFRS translation & \\
\hline & $2001-2003$ & $\begin{array}{l}\text { Accounting Act } \\
\text { amendment in the regard } \\
\text { of IFRS implementation }\end{array}$ & & \\
\hline & 2001 & $\begin{array}{l}\text { General chart of accounts } \\
\text { issued }\end{array}$ & & \\
\hline & 2004 & \multicolumn{2}{|c|}{ Joined the EU } & \\
\hline & 2005 & & Adoption & \\
\hline \multirow[t]{4}{*}{$\begin{array}{l}\text { Estonia } \\
\text { (12 years) }\end{array}$} & 1990-1991 & $\begin{array}{l}\text { Adoption of the } \\
\text { Regulation of Accounting }\end{array}$ & & \multirow[t]{4}{*}{ Alver et al., 2014} \\
\hline & 2003 & & Adoption & \\
\hline & 2004 & \multicolumn{2}{|c|}{ Joined the EU } & \\
\hline & 2005 & & IFRS translation & \\
\hline \multirow{4}{*}{$\begin{array}{l}\text { Lithuania } \\
\text { (8 years) }\end{array}$} & 1997 & Accounting Law issued & IAS translated & \multirow[t]{4}{*}{ Mackevicius, et al., 2008} \\
\hline & 2001 & $\begin{array}{ll}\text { New } & \text { Accounting } \\
\text { Regulation } & \\
\end{array}$ & & \\
\hline & 2004 & \multicolumn{2}{|c|}{ Joined the EU } & \\
\hline & 2005 & & Adoption & \\
\hline \multirow{3}{*}{$\begin{array}{l}\text { Croatia } \\
\text { (13 years) }\end{array}$} & 1992-1993 & Accounting Act & First translation of IAS & \multirow[t]{5}{*}{ Sodan and Barac, 2017} \\
\hline & 2005 & New Accounting Act & $\begin{array}{l}\text { IFRS translation, } \\
\text { Adoption }\end{array}$ & \\
\hline & 2013 & \multicolumn{2}{|c|}{ Joined the EU } & \\
\hline \multirow[t]{4}{*}{$\begin{array}{l}\text { Latvia } \\
\text { (13 years) }\end{array}$} & 1992 & $\begin{array}{l}\text { Accounting and } \\
\text { Accounting Reporting } \\
\text { Laws }\end{array}$ & & \\
\hline & 1993 & $\begin{array}{l}\text { Chart of Accounts } \\
\text { approved }\end{array}$ & & \\
\hline & 2002 & New Law On Accounting & & \\
\hline & 2005 & & Adoption & \\
\hline Poland & 1994 & Act On Accounting & & Krzywda and Schroeder, \\
\hline (11 years) & 2000 & New Accounting Act & & \\
\hline & 2004 & & IFRS translation & \\
\hline & 2005 & Joined the EU & Adoption & \\
\hline Russia (18 & 1994 & Law On Accounting & & McGee and \\
\hline years) & 1998 & $\begin{array}{l}\text { Government Decree "On } \\
\text { approval of the } \\
\text { accounting reform } \\
\text { program in accordance } \\
\text { with the IFRS" }\end{array}$ & & $\begin{array}{l}\text { Preobrazhenskaya, 2005; } \\
\text { Vysotskaya and } \\
\text { Prokofieva, 2013 }\end{array}$ \\
\hline & 2004 & $\begin{array}{l}\text { "Concept of development } \\
\text { of accounting and } \\
\text { reporting in the } \\
\text { Russian Federation in the } \\
\text { medium term" }\end{array}$ & & \\
\hline & 2010 & & $\begin{array}{l}\text { Adopted by listed companies } \\
\text { and credit organizations }\end{array}$ & \\
\hline
\end{tabular}




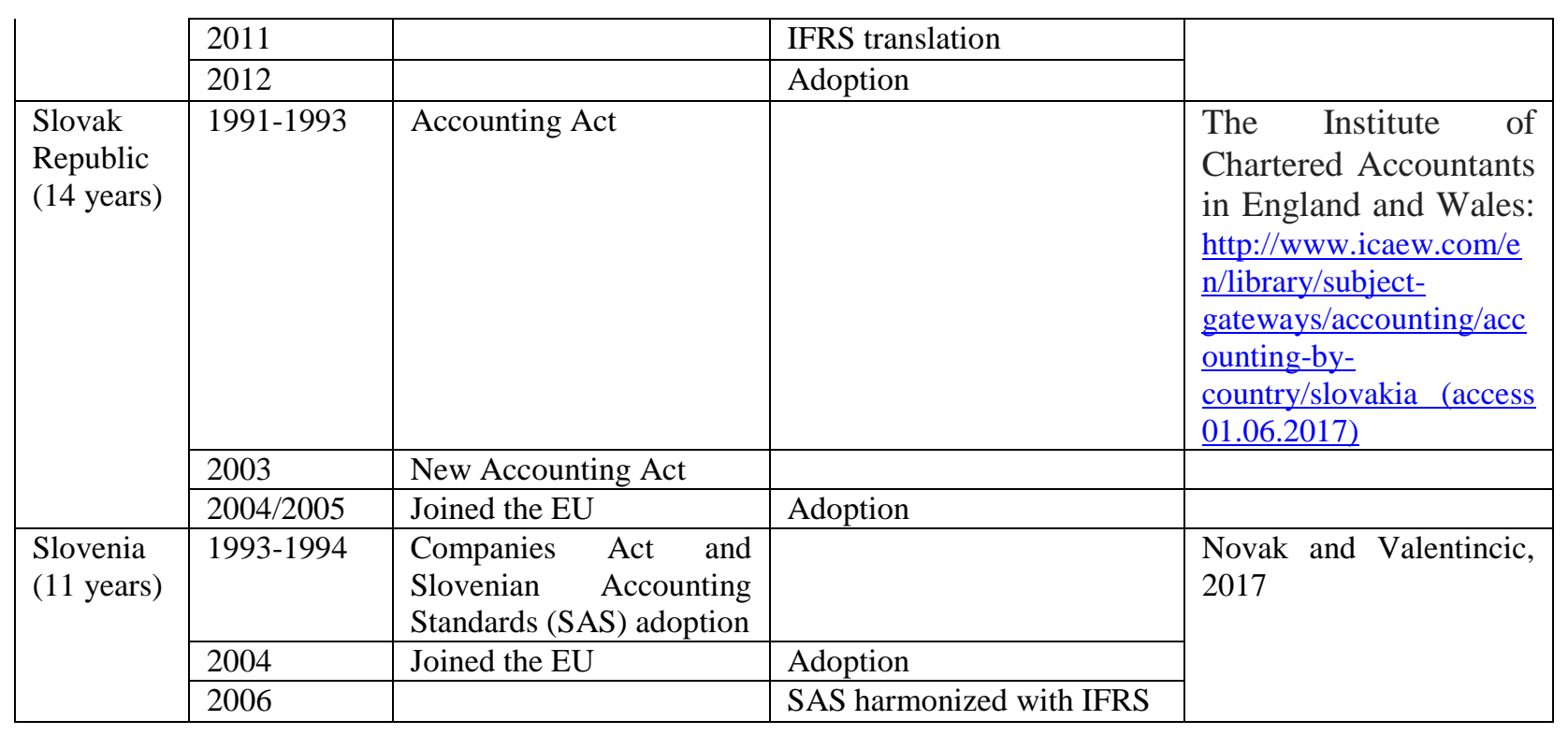

Table 2. Sample Distribution, Regulatory Quality, and Effective Date of IFRS adoption ${ }^{6}$

\begin{tabular}{|l|l|l|}
\hline Country & South Korea & Russia \\
\hline Observations in Sample & 45 & 130 \\
\hline Percentage of IFRS users & $22.22 \%$ & $3.08 \%$ \\
\hline Regulatory Quality 2003 (i) & 0.749 & -0.183 \\
\hline Adoption of IFRS (effective date) & 2011 & 2012 \\
\hline $\begin{array}{l}\text { Country Specific Rules for Non- } \\
\text { Listed Firms on Adoption of IFRS }\end{array}$ & C + U is permitted for all entities & $\begin{array}{l}\text { C is required for entities who are } \\
\text { obliged by federal laws or } \\
\text { constitutive documents }\end{array}$ \\
\hline
\end{tabular}

Figure 1. IFRS adoption period taken by Balto-Slavic countries

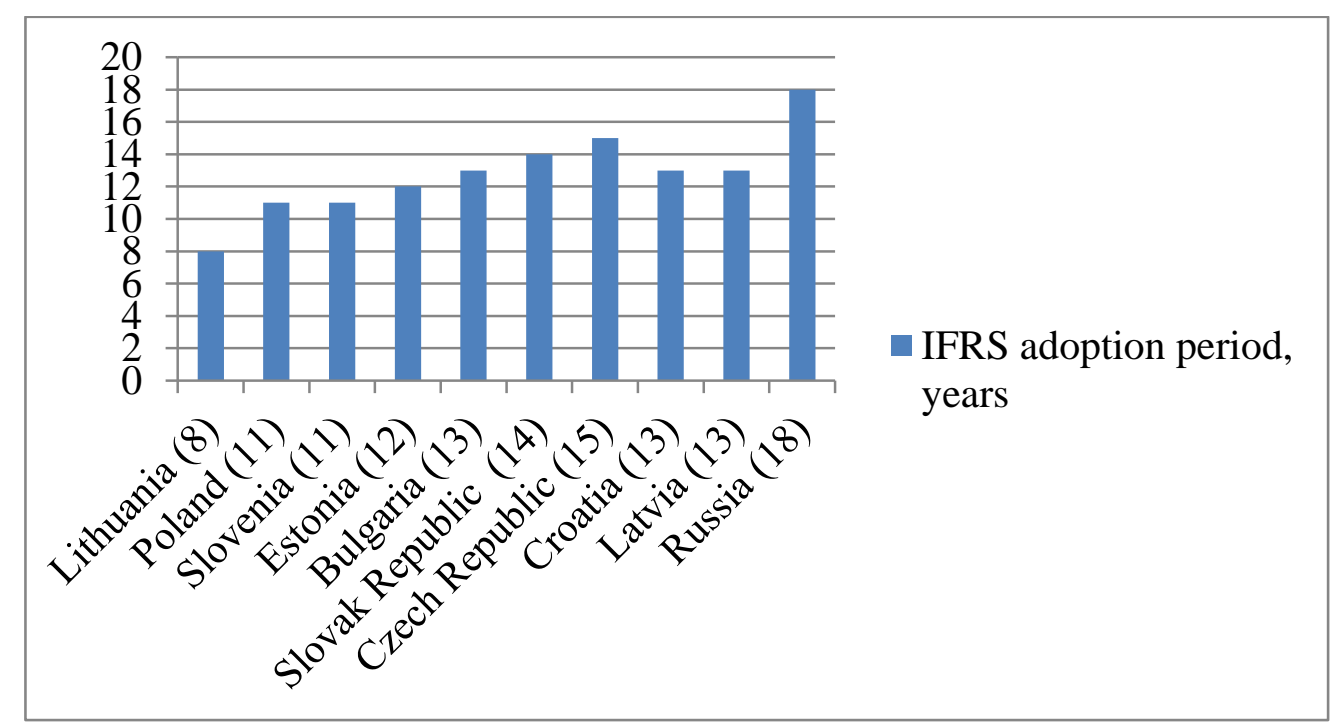

\footnotetext{
${ }^{6}$ Source of the data: Balsmeier and Vanhaverbeke (2016)
} 
Figure 2. Quantity of available in database text books

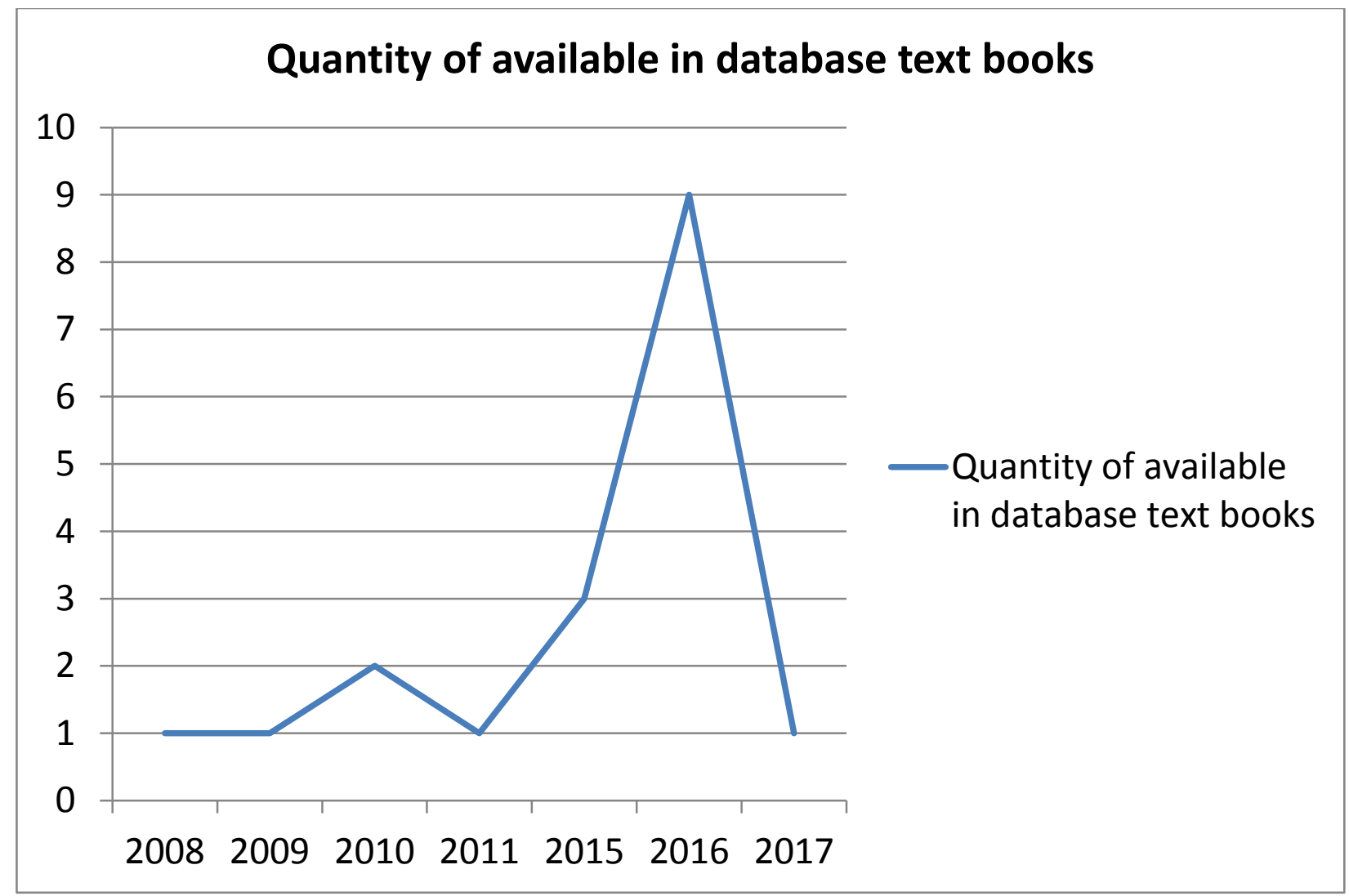

Figure 3. IFRS teaching resources in Russian language and English language references 


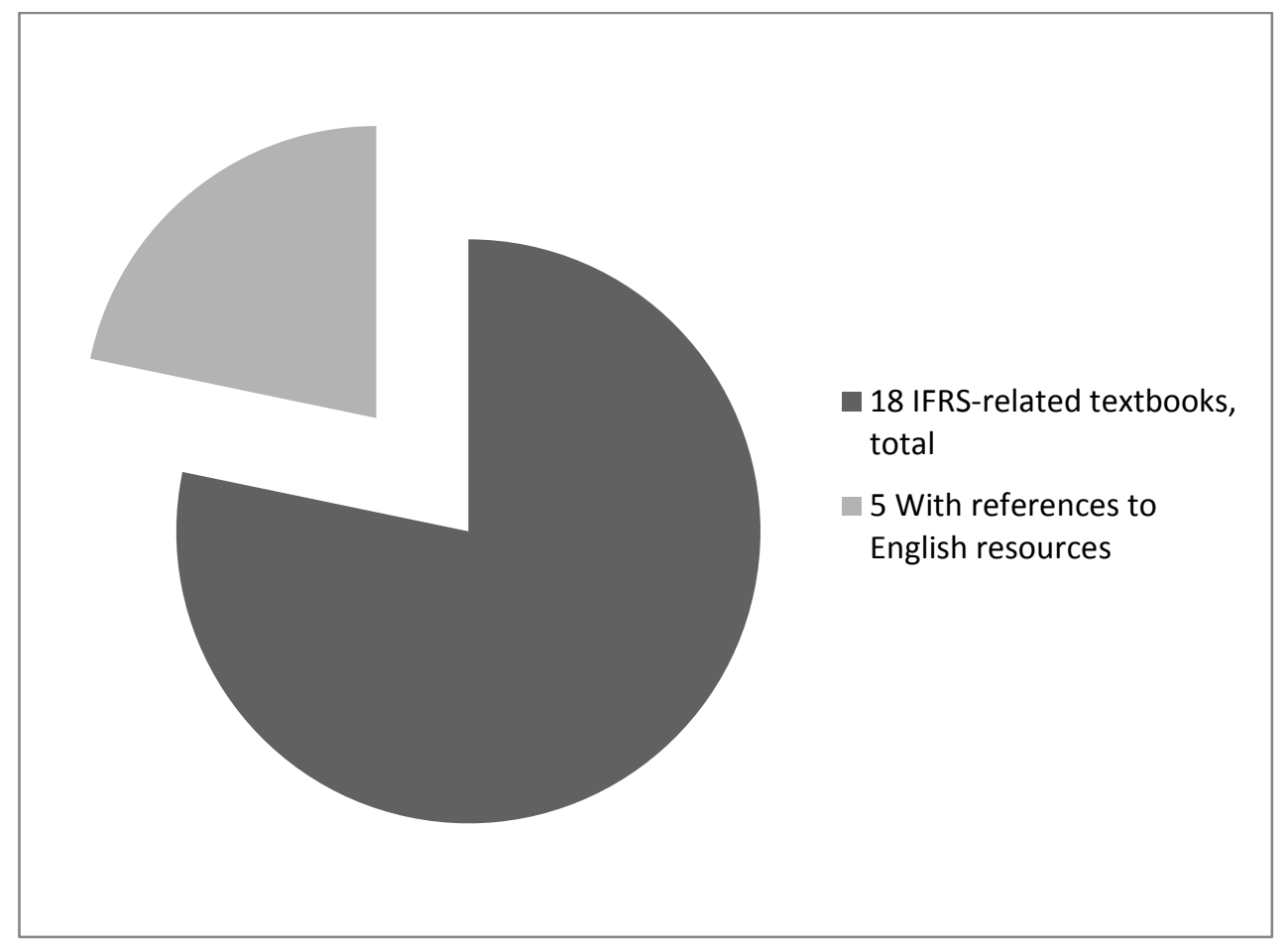

Figure 4. Geographical distribution of first author's affiliations

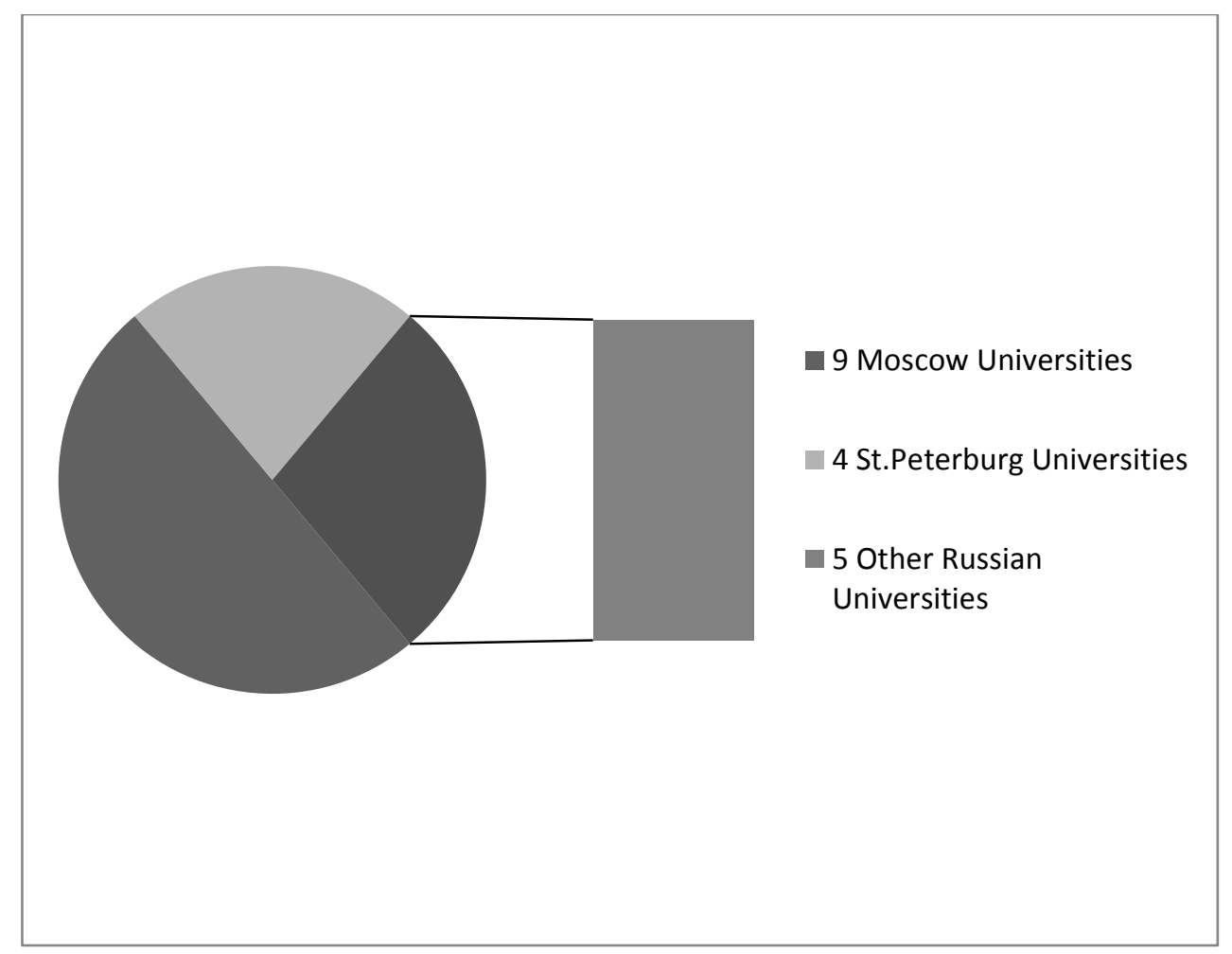

Figure 5. International Visibility of Russian IFRS Education Authors 


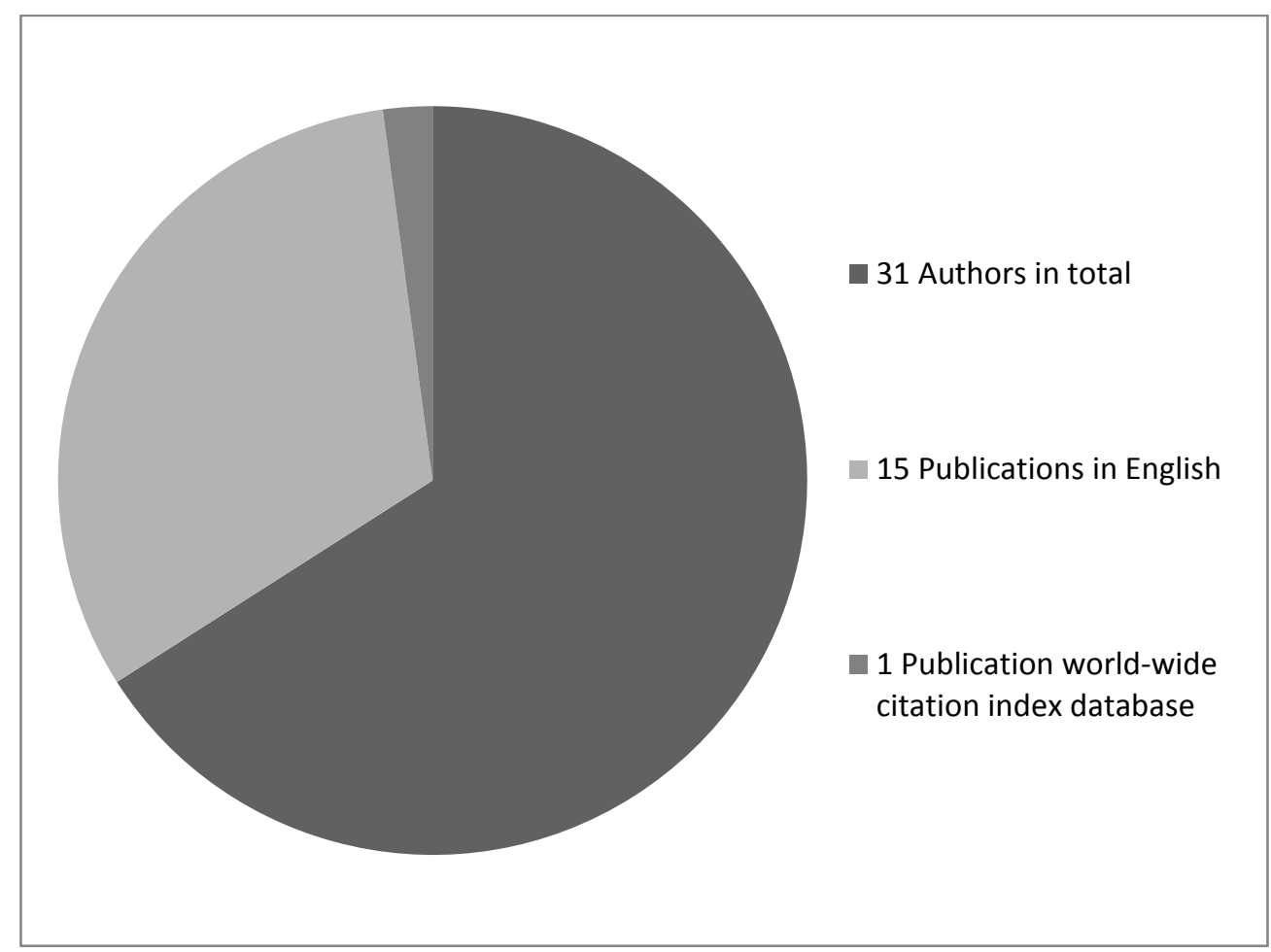

Figure 6. Actors for international IFRS adoption

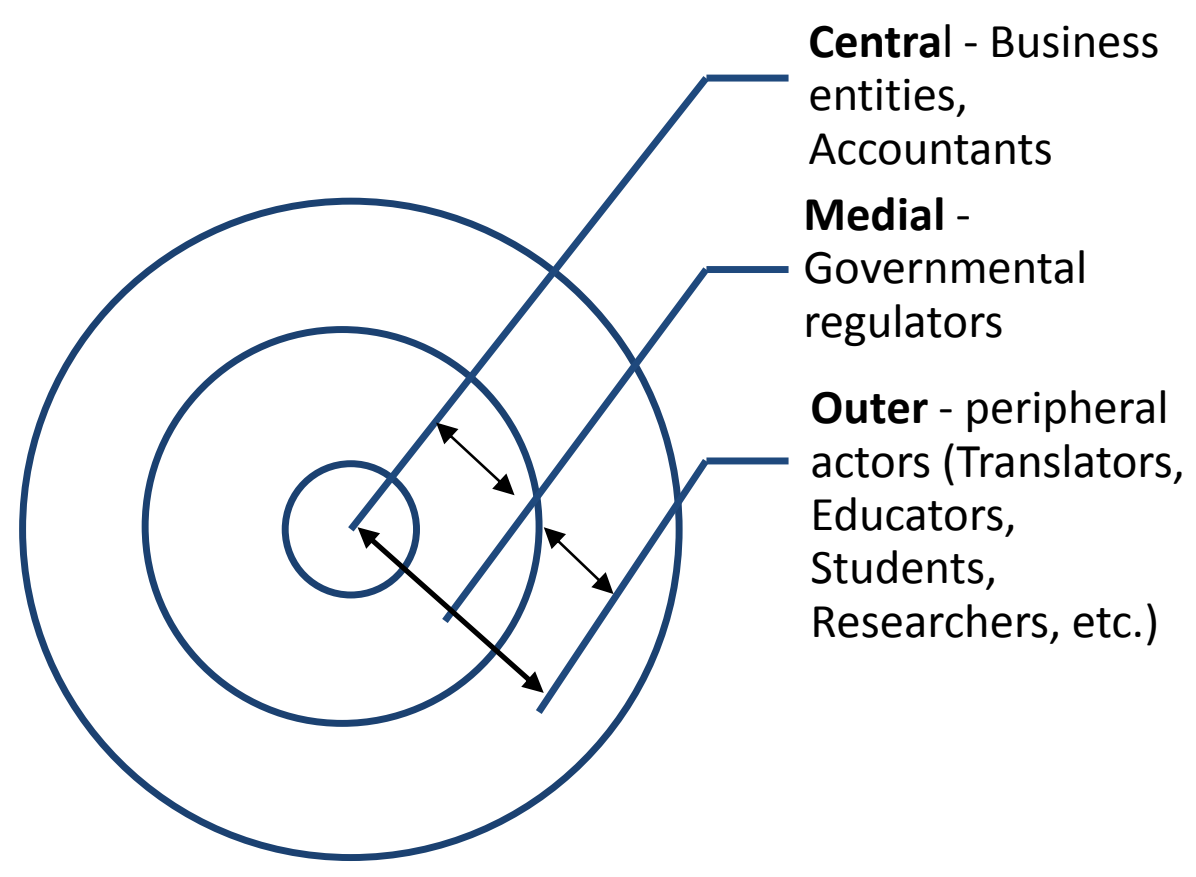




\section{Evaluative Research Questionnaire: Issues in teaching IFRS}

\section{IFRS Classes}

\begin{tabular}{|c|c|c|c|c|c|c|c|}
\hline & $\begin{array}{l}\text { Statements about the IFRS classes/ } \\
\text { /For each of the following statements, please rate you level of } \\
\text { agreement or disagreement by marking an X in the appropriate } \\
\text { column/ }\end{array}$ & 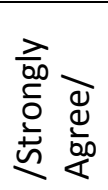 & 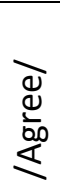 & 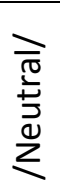 & 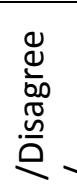 & 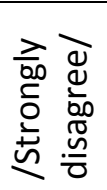 & 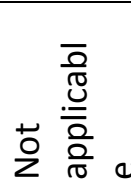 \\
\hline 1 & $\begin{array}{l}\text { IFRS classes are more difficult than other course in the } \\
\text { current year of the degree. }\end{array}$ & & & & & & \\
\hline 2 & IFRS classes are interesting. & & & & & & \\
\hline 3 & $\begin{array}{l}\text { I believe that IFRS classes have provided a sound } \\
\text { foundation for my further studies in accounting. }\end{array}$ & & & & & & \\
\hline 4 & IFRS classes were more interesting than expected. & & & & & & \\
\hline 5 & $\begin{array}{l}\text { IFRS classes improve my knowledge and } \\
\text { understanding of accountancy and auditing. }\end{array}$ & & & & & & \\
\hline 6 & $\begin{array}{l}\text { After studying for IFRS classes I am more interested in } \\
\text { accounting than I was before. }\end{array}$ & & & & & & \\
\hline 7 & $\begin{array}{l}\text { After studying for IFRS classes I am now more } \\
\text { motivated to pursue a specialist qualification in } \\
\text { accounting. }\end{array}$ & & & & & & \\
\hline 8 & $\begin{array}{l}\text { After studying for IFRS classes I am now more } \\
\text { motivated to pursue a future career in accounting. }\end{array}$ & & & & & & \\
\hline 9 & I enjoyed IFRS classes & & & & & & \\
\hline 10 & $\begin{array}{l}\text { The lectures on the IFRS in English helped me } \\
\text { understand the subject. }\end{array}$ & & & & & & \\
\hline 11 & $\begin{array}{l}\text { The course textbook for the course was more helpful } \\
\text { than the lectures and workshops. }\end{array}$ & & & & & & \\
\hline 12 & $\begin{array}{l}\text { Do you think that in understanding IFRS non-English } \\
\text { speaking students face more difficulties? }\end{array}$ & & & & & & \\
\hline 13 & $\begin{array}{l}\text { Do you think that in explaining IFRS by non-English } \\
\text { speaking lecturers there are more difficulties? }\end{array}$ & & & & & & \\
\hline
\end{tabular}

\section{Other Questions about IFRS classes}

Do you know that the IASB accepts commentaries and feedback on an open-access basis? If yes, let us know how did you learn about this?

\section{Further Questions}

Please tick the appropriate item or write your answer in the space provided

\begin{tabular}{|l|l|l|l|}
\hline What is your intended degree specialization/major? & & \\
\hline Other (please specify) & Male & & Female \\
\hline Gender & & & \\
\hline Year of study on the degree & & \\
\hline Age & & \\
\hline Name & & \\
\hline Student number & & \\
\hline
\end{tabular}


